\title{
Mechanism of Regulatory T Cells During Allergen-Specific Immunotherapy: from the Past to Future
}

\section{Yi-Giien Tsai ${ }^{1}$ and Ching-Yuang Lin ${ }^{2 *}$}

${ }^{1}$ Departments of Pediatrics, Changhua Christian Hospital, School of Medicine, Chung Shan Medical University, Taichung, Taiwan ${ }^{2}$ Clinical Immunological Center, China Medical University Hospital, College of Medicine, China Medical University, Taichung, Taiwan

\begin{abstract}
Allergen-specific subcutaneous immunotherapy (SCIT) has been effective used for the treatment choice for allergic rhinitis and asthma. Although it is clear that SCIT reduces the symptoms of allergic disease and can alter the natural course of allergic disease, however, the basic immunologic mechanisms involved in the amelioration of the allergic symptoms are still unknown. Recent studies suggest that the induction of $\mathrm{CD} 4^{+} \mathrm{CD} 25^{+} \mathrm{Foxp} 3^{+}$Treg cells and IL-10-secreting type 1 Treg cells might be associated with suppression of allergic responses in patients after successful SIT. IL-10 and TGF- $\beta$ from CD4+ Treg cells have proven essential roles in the maintenance of immunological self-tolerance in the $\mathrm{CD} 4^{+} \mathrm{T}$ cell compartment and inhibit Th2 cytokines releasing and differentiation Evidences suggest that the shift from Th2 to Th1 induced by SIT might be mediated by induction of the apoptosis in mite allergen-responder CD4 $4^{+} \mathrm{L}-4^{+}$Th2 cells in asthmatic children. We noted a significant increase in CD $8^{+}$Foxp3 ${ }^{+}$ Treg cells population expressing intracellular IL-10 and granzyme B can be generated by continuous allergen stimulation following six months of SCIT. We further demonstrated that CD8 ${ }^{+}$Treg cells, but not CD4+ Treg cells, can enhance $\mathrm{CD} 4{ }^{+} \mathrm{CD} 45 \mathrm{ROhi}{ }^{+}$cell apoptosis. TLR2 agonist stimulates endogenous $\mathrm{CD} 4{ }^{+} \mathrm{CD} 25 \mathrm{hi}^{+}$Treg cells to produce IL-10, and may support another mechanism for the treatment of allergic disease. Future perspectives are required to clarify the precise Treg subsets involved SIT and develop clinical efficacious and safer allergen vaccines by utilizing the Treg cells functions.
\end{abstract}

Keywords: Immunotherapy; Allergen-specific subcutaneous immunotherapy (SCIT); CD4 ${ }^{+} \mathrm{CD} 25^{+}$Foxp3+ Treg Cells; TGF-B; GATA-3; CD8 ${ }^{+} \mathrm{CD} 25^{+} \mathrm{Foxp}^{+}$; CD4 ${ }^{+} \mathrm{CD} 25 \mathrm{hi}^{+}$Treg Cells

Abbreviations: Der p: Dermatophagoides pteronyssinus; Treg: Regulatory T; SCIT: Subcutaneous Immunotherapy; SIT: Specific Immunotherapy; SLIT: Sublingual Immunotherapy

\section{Introduction}

Since the first trial reported by Noon about a century ago [1], allergen-specific immunotherapy (SIT) by repeated subcutaneous administration of increased doses of allergen extracts has a long-lasting effect on immunologic tolerance to common environmental allergens [2-4]. Allergen-specific subcutaneous immunotherapy (SCIT) has been effectively used for the treatment choice for allergic rhinitis and asthma $[5,6]$. It is clear that SCIT reduces the symptoms of allergic disease and can alter the natural course of allergic disease, however, the basic immunologic mechanisms involved in the amelioration of the allergic symptoms are becoming better understanding in recent years.

For decades it has been postulated that allergen-specific IgG presents in serum and secretions may block allergen before it interacts with cell-bound IgE. This blocking activity is likely to have some relevance in the protective effect of venom SIT but is unlikely to be a major mechanism with inhalant allergens [7]. Several changes in cytokines profiles of T cells, such as increased production of IFN- $\gamma$ and a reduction of IL- 4 in atopic patients undergoing SIT, suggest that a shift in the balance between the lymphocyte responses from Th2 to Th1 is involved in the SIT mechanism [2-4]. However, some studies failed to show any changes in Th1 cytokine production by SIT [8]. The Th1 and Th2 balance thesis has been abandoned after the description of the regulatory $\mathrm{T}$ cells (Treg), recent accumulating evidences suggest that the induction of $\mathrm{CD} 4^{+}$regulatory $\mathrm{T}$ cells might be associated with suppression of allergic responses in patients after successful SIT [9-11].

\section{Functional Treg cells in asthma}

Subsets of Treg cells with distinct phenotypes have received particular attention: the naturally thymus-selected $\mathrm{CD} 4^{+} \mathrm{CD} 25^{+} \mathrm{Foxp} 3^{+}$ Treg cells [12] and the inducible type 1 IL-10 secreting Treg cells ( $\operatorname{Tr} 1$ cells) and TGF $\beta$ - secreting Th3 cells [13], which are generated in the periphery under various tolerogenic conditions. Regulatory $\mathrm{T}$ cells (Treg) are clearly pivotal for maintenance of immune self-tolerance, including unresponsiveness of $\mathrm{T}$ cells to exogenous allergen or active peripheral tolerance induction [12-14]. Various evidences revealed Treg cells play important roles in the control of autoimmune diseases, allergic disorders, infections and cancer development [15-17].

$\mathrm{CD} 4{ }^{+} \mathrm{CD} 25 \mathrm{hi}^{+}$regulatory $\mathrm{T}$ cells was a minor fraction (approximately 10\%) of $\mathrm{CD}^{+} \mathrm{T}$ cells that play a critical role in the maintenance of self-tolerance during allergy. $\mathrm{CD} 4^{+} \mathrm{CD} 25^{+} \mathrm{T}$ cells have been shown to inhibit the development of airway eosinophilia and CD4+CD25+ T cells could suppress immune responses through direct cell-cell contact in a process that is dependent on signaling via secretion of TGF- $\beta$ and IL-10 [18]. Treg cells modulate allergen-specific antibody production, suppress IgE production and directly or indirectly suppress effector cells of allergic inflammation such as mast cells, eosinophils

*Corresponding author: Ching-Yuang Lin, Associate Dean, Clinical Immunologica Center, China Medical University Hospital, College of Medicine, China Medical University, Taichung, Taiwan, Tel: +886-4-2207 1501; Fax: +886-4-2207 1352; E-mail: cylin@mail.cmuh.org.tw

Received September 22, 2011; Accepted November 21, 2011; Published November 25, 2011

Citation: Tsai YG, Lin CY (2011) Mechanism of Regulatory T Cells During Allergen-Specific Immunotherapy: from the Past to Future. J Aller Ther S口:00!. doi:10.4172/2155-6121.S]-00]

Copyright: ( 2011 Tsai YG, et al. This is an open-access article distributed unde the terms of the Creative Commons Attribution License, which permits unrestricted use, distribution, and reproduction in any medium, provided the original author and source are credited. 
and basophils $[19,20]$. Treg cells also down-regulate the expression of CD80/CD86 on dendritic cells and inhibiting the pro-inflammatory effects $[21,22]$.

Loss of Treg cells function appears to be a critical factor in the pathogenesis of human allergic asthma. Cumulative evidences show defective immunoregulation in $\mathrm{CD}^{+}$regulatory $\mathrm{T}$ cells (Treg) function to control allergic inflammation in asthmatic subjects [11,23]. Evidence from pediatric asthmatic subjects demonstrated $\mathrm{CD} 4{ }^{+} \mathrm{CD} 25 \mathrm{hi}^{+}$Treg cells are decreased in the bronchoalveolar lavage fluid and fail to inhibit pulmonary Th2 responses, suggesting the functional defective recruitment of Treg cells to the site of airway inflammation [24]. Attention has been focused on defects of natural occurring $\mathrm{CD} 4^{+} \mathrm{CD} 25^{+}$ Treg cells to regulate inflammatory response in asthmatic subjects, however, the adaptive regulatory $\mathrm{T}(\mathrm{Tr} 1)$ cells and $\mathrm{CD} 8^{+}$regulatory $\mathrm{T}$ cells, which secrete the immunosuppressive cytokines, may also play cardinal role to maintain immune tolerance with allergen in asthma [25-27]. The identification and isolation of highly purified, functional Tregs can be challenging and time-consuming for cutting-edge Treg research. The present used conventional Treg markers, such as CD25 and CTLA-4, are not fully specific to represent inducible Tregs, such as TGF $\beta$ - secreting Th3 and Tr1 cells. Although that, further studies are needed to understand all of the signals that differentially affect $\mathrm{Th} 2$ and $\mathrm{T}$ regulatory cells development and the relationship of tolerance to the pathogenesis of allergic disease and asthma.

\section{Conventional $\mathrm{CD}^{+}{ }^{+}$Treg cells during SIT}

Allergen specific immunotherapy (SIT), which induces the generation of Treg cells to maintain allergen tolerance, has emerged as the most reasonable approach in the management of allergic disorders. Recent studies suggest that the induction of CD4+CD25+ Foxp3+ Treg cells and IL-10-secreting type 1 Treg cells might be associated with suppression of allergic responses in patients after successful SIT [2-4]. SIT improved the symptoms of asthma and decreased airway inflammation by the induction of $\mathrm{CD} 4^{+} \mathrm{CD} 25^{+}$regulatory $\mathrm{T}$ (Treg) cells with anti-inflammatory cytokines such as IL-10 and TGF- $\beta$ [28].

Evidences suggest IL-10 and TGF- $\beta$ have proven essential roles in the maintenance of immunological self-tolerance in the $\mathrm{CD}^{+} \mathrm{T}$ cell compartment during SIT [29]. Peripheral T cell tolerance after SIT is characterized by decreased Th2 cytokine release and suppressed antigen-driven proliferative $\mathrm{T}$ cell responses in an IL-10-dependent manner [30]. The mechanism of action by IL-10 from Treg cells during IT was observed including, suppresses allergen-specific IgE, induces allergen-specific IgG4 and blocks CD28-costimulatory molecule signaling pathway of antigen presenting cells [10,19-22,29]. In addition, TGF- $\beta$ induces the expression of Foxp3, which promotes the induction of Treg cells with potent regulatory property [31-33]. It also inhibits the differentiation of Th2 cells by inhibiting the expression of transcription factors GATA-3 [34].

Asthma is characterized by chronic airway inflammation with several increased inflammatory cytokines. The transcription factor NF- $\mathrm{kB}$ subunits, $\mathrm{p} 65$ and $\mathrm{p} 50$, play an important role in immune and inflammatory responses. We further noted that Dermatophagoides pteronyssinus (Der p) SIT could induce anti-inflammatory cytokines, IL-10, TGF- $\beta$ and $\mathrm{sCD} 14$, correlated with improved pulmonary function by inhibiting nuclear NF- $\mathrm{kB} / \mathrm{p} 65$ expression. The finding of a correlation between improved lung function and the various anti- inflammatory cytokines raises interesting questions about whether strategies that can achieve a higher level of Treg cells with IL-10 or TGF- $\beta$ during SIT might be more effective therapy for asthma [11].

\section{Emerging roles of $\mathrm{CD8}^{+}$Treg cells during SIT}

While the majority of research is focus on $\mathrm{CD} 4^{+}$Treg function, less known about the role of $\mathrm{CD} 8^{+}$Treg cells during asthma. CD8 ${ }^{+}$Treg cells with regulatory function expressing transcription factor Foxp3 and Involvement of $\mathrm{CD}^{+}$Tregs in maintaining self-tolerance has recently been identified [35-37]. Human $\mathrm{CD}^{+}$Treg cells are implicated in various infectious diseases [38,39] and autoimmune disorders [40,41].

With numbers of $\mathrm{CD} 8^{+}$Tregs cells are relatively small in peripheral blood, $\mathrm{CD}^{+} \mathrm{CD} 25^{+} \mathrm{Foxp}^{+} \mathrm{T}$ cells can be generated by continuous antigen stimulation and $\mathrm{T}$ cell receptor stimulation $[42,43]$. CD8 ${ }^{+}$Tregs cells can suppress cellular proliferation of $\mathrm{CD} 4^{+}$naïve and effector T cells via cell-cell contact lysis or soluble factors like IL-10 and TGF- $\beta$ [4446]. Systemic immunization with allergen in mice induces $\mathrm{CD}^{+}$Treg cells that can inhibit the development of allergic diarrhea, suggesting $\mathrm{CD}^{+}$Treg cells may play a pivotal role in limiting allergic disease [47]. Der $p$ SIT by repeated antigen stimulation may augment $\mathrm{CD}^{+}$Terg population and amplify the mechanism of immune tolerance. We noted a significant increase in $\mathrm{CD} 8^{+} \mathrm{Foxp} 3^{+}$Treg cells population expressing intracellular IL-10 and granzyme B following 6 months of SIT [27].

\section{Functional $\mathrm{CD}^{+}$Treg cells induced Th2 apoptosis during SIT}

Apoptosis, a specific morphological feature of activation-induced cell death, can maintain T-lymphocytes homeostasis [48]. In allergic asthma, the over-activation of lymphocytes and eosinophils were found to accumulate in the airway inflammation tissues, partly because of their prolonged survival [49].

Apoptosis of allergen-specific Th2 cells during SIT represents a unique down-regulatory mechanism that prevents the continuous activation of Th2 immune responses by allergen. Some evidence suggested allergen induced apoptosis of $\mathrm{T}$ lymphocytes in allergen specific IT treated atopic patients [50]. Guerra et al. reported that peripheral blood mononuclear cells (PBMC) culture of $48 \mathrm{~h}$ with grass allergen induced apoptosis of Th2 cells from grass IT treated patients [51]. Our previous results indicated that the shift from Th2 to Th1 induced by allergen-specific IT might be mediated by induction of the apoptosis in mite allergen-responder CD $4^{+} \mathrm{IL}-4^{+} \mathrm{Th} 2$ cells in asthmatic children [52]. We further demonstrated that $\mathrm{CD}^{+}$Treg cells, but not $\mathrm{CD}^{+}{ }^{+}$Treg cells, can enhance $\mathrm{CD} 4^{+} \mathrm{CD} 45 \mathrm{ROhi}^{+}$cell apoptosis. Cell contact with $\mathrm{CD}^{+}$Treg cells expressing increased granzyme $\mathrm{B}$ may induce cell apoptosis of $\mathrm{CD}^{+} \mathrm{CD}^{2} 5 \mathrm{RO}^{+}$memory $\mathrm{T}$ cells during SIT [27].

\section{Sublingual allergen-specific IT and Treg cells}

The clinical efficacy of sublingual specific allergen immunotherapy (SLIT) as an alternative to subcutaneous immunotherapy has been confirmed in evidence practice [53]. Elevated levels of recent evidences suggest SLIT induces IL-10-producing T regulatory cells to maintain allergen- specific T-cell tolerance and immune deviation [54-56]. The mechanisms of SLIT to induction of Treg cells are not fully understood, the mucosal dendritic cells play a potential role in the induction of allergen-specific tolerance and may prime Foxp $3^{+}$Treg cells to produce IL-10, TGF- $\beta$ [57-59].

\section{Toll like receptors enhance Treg cells may benefit in SIT}

To further increase efficacy of SIT, a novel therapeutic strategy is to 


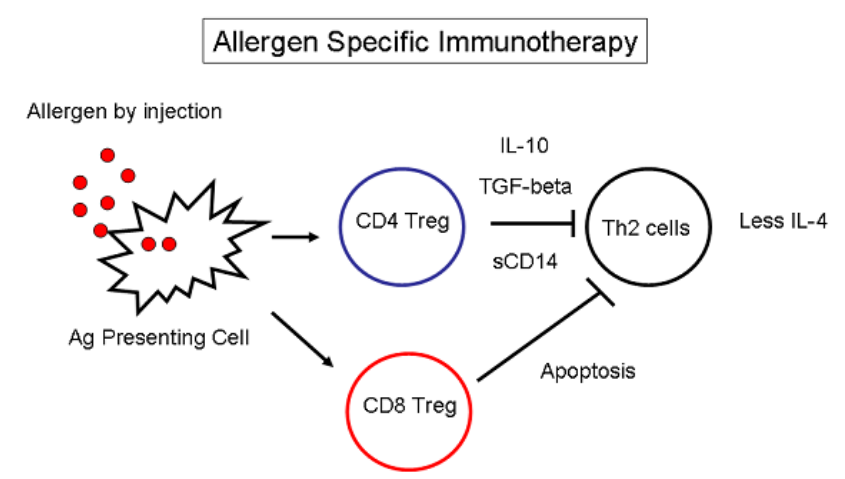

Figure 1: Brief summary of the mechanism of Treg cells to maintain immune tolerance during immunotherapy. Our results indicated that Th2 cells anergy and the relationship of immune tolerance during IT might be mediated by induction of $\mathrm{CD} 4^{+}$Treg cells and $\mathrm{CD} 8^{+}$Treg cells with anti-inflammatory cytokine that produced soluble CD14, IL-10, and TGF- $\beta$. CD $8^{+} C D 25^{+}$Tregs, but not $\mathrm{CD} 4^{+} \mathrm{CD} 25^{+}$Tregs, directly induced allergen induced CD4+CD45ROhi+ cells apoptosis.

develop combined adjuvant vaccine with Toll like receptors (TLR) via promoting expansion and function of Treg cells. TLRs, when responding to microbial signals, may have an important role in the development of allergy [60]. A number of future forms of immunotherapy may provide better alternatives to the currently available SCIT or SLIT, including combination of conventional SCIT with CpG (a synthetic TLR 9 ligand) $[61,62]$ and Pam3CSK4 (a synthetic TLR receptor 2 ligand) $[27,63]$

TLR2 agonist stimulate endogenous $\mathrm{CD} 4{ }^{+} \mathrm{CD} 25 \mathrm{hi}^{+}$Treg cells to produce IL-10, and may support another mechanism for the treatment of allergic disease [64]. It has been demonstrated that TLR2 synthetic agonist Pam3CSK4 has therapeutic potential to decrease mite allergeninduced $\mathrm{Th} 2$ immune response and thus may be useful as adjuvant in immunotherapy for allergic disease [63,65]. Co-stimulation of PBMCs with Pam3CSK4 and Der p 2 expanded the $\mathrm{CD} 8^{+} \mathrm{CD} 25^{+} \mathrm{Foxp}^{+}$Treg population and inhibited Der $\mathrm{p} 2$-induced IL-4 production may benefit in SIT [27].

\section{Brief Summary of Treg cells during SIT}

Functional $\mathrm{CD}^{+}$Treg cells play important roles in reducing Th2-mediated allergic inflammation and modulate allergen induced tolerance during SIT. However, the interaction between the two subsets of $\mathrm{CD}^{+}$and $\mathrm{CD}^{+}$Treg cells that protect against allergy remains unclear. Th2 cells anergy and the relationship of immune tolerance during SIT might be mediated by induction of $\mathrm{CD} 4^{+}$Treg cells and $\mathrm{CD}^{+}$Treg cells with anti-inflammatory cytokine. CD8 ${ }^{+} \mathrm{Foxp}^{+}{ }^{+}$Treg cells can induce apoptosis of Der p-2 induced CD4 ${ }^{+} \mathrm{CD} 45 \mathrm{ROhi}^{+}$cells and suppress $\mathrm{CD} 4^{+} \mathrm{T}$ cells proliferation by cell-contact inhibition may benefit the immune tolerance during SIT (as summary in Figure 1). Future perspectives are required to clarify the precise Treg subsets involved SIT and develop clinical efficacious and safer allergen vaccines by utilizing the Treg cells functions.

\section{Acknowledgments}

This work was partially supported by grants from the National Science Council, Taiwan, ROC (NSC 100-2314-B-371 -005); and grants from Changhua Christian Hospital

\section{Reference}

1. Noon L (1911) Prophylactic inoculation against hay fever. Lancet i:1572-1573.

2. Jutel M, Akdis CA (2011) Immunological mechanisms of allergen-specific immunotherapy. Allergy 66: 725-732.
3. Shamji MH, Durham SR (2011) Mechanisms of immunotherapy to aeroallergens. Clin Exp Allergy 41: 1235-1246.

4. Akdis M, Akdis CA (2007) Mechanisms of allergen-specific immunotherapy. J Allergy Clin Immunol 119: 780-791.

5. Abramson MJ, Puy RM, Weiner JM (2003) Allergen immunotherapy for asthma. Cochrane Database Syst Rev 4: CD001186.

6. Calderon MA, Alves B, Jacobson M, Hurwitz B, Sheikh A, et al. (2007) Allergen injection immunotherapy for seasonal allergic rhinitis. Cochrane Database Syst Rev 1: CD001936.

7. Ozdemir C, Kucuksezer UC, Akdis M, Akdis CA (2011) Mechanisms of immunotherapy to wasp and bee venom. Clin Exp Allergy 41: 1226-1234.

8. Wachholz PA, Nouri-Aria KT, Wilson DR, Walker SM, Verhoef A, et al. (2002) Grass pollen immunotherapy for hayfever is associated with increases in local nasal but not peripheral Th1: Th2 cytokine ratios. Immunology 105: 56-62.

9. Francis JN, Till SJ, Durham SR (2003) Induction of IL- $10^{+} \mathrm{CD} 4^{+} \mathrm{CD} 25^{+} \mathrm{T}$ cells by grass pollen immunotherapy. J Allergy Clin Immunol 111:1255-1261.

10. Jutel M, Akdis M, Budak F, Aebischer-Casaulta C, Wrzyszcz M, et al. (2003) IL10 and TGF- $\beta$ cooperate in the regulatory T cell response to mucosal allergens in normal immunity and specific immunotherapy. Eur J Immunol 33: 1205-1214.

11. Tsai YG, Chiou YL, Chien JW, Wu HP, Lin CY (2010) Induction of IL-10+ $\mathrm{CD}^{+} \mathrm{CD}^{2} 5^{+}$regulatory $\mathrm{T}$ cells with decreased NF-KB expression during immunotherapy. Pediatr Allergy Immunol 21: e166-173.

12. Sakaguchi S, Miyara M, Costantino CM, Hafler DA (2010) FOXP3 $3^{+}$regulatory T cells in the human immune system. Nat Rev Immunol 10: 490-500.

13. Vignali DAA, Collison LW, Workman CJ (2008) How regulatory T cells work. Nat Rev Immunol 8: 523-532.

14. Sakaguchi S, Yamaguchi T, Nomura T, Ono M (2008) Regulatory T cells and immune tolerance. Cell 133: 775-787.

15. Read S, Malmstrom V, Powrie F (2000) Cytotoxic T Iymphocyte-associated antigen 4 plays an essential role in the function of $C D 25^{+} C D 4^{+}$regulatory cells that control intestinal inflammation. J Exp Med 192: 295-302.

16. Salomon B, Lenschow DJ, Rhee L, Ashourian N, Singh B, et al. (2000) B7/ CD28 costimulation is essential for the homeostasis of the CD4+CD25 immunoregulatory $\mathrm{T}$ cells that control autoimmune diabetes. Immunity 12 $431-440$.

17. Palomares O, Yaman G, Azkur AK, Akkoc T, Akdis M, et al. (2010) Role of Treg in immune regulation of allergic diseases. Eur J Immunol 40: 1232-1240.

18. Bellinghausen I, Konig B, Bottcher I, Knop J, Saloga J (2006) Inhibition of human allergic T-helper type 2 immune responses by induced regulatory T cells requires the combination of interleukin-10-treated dendritic cells and transforming growth factor-beta for their induction. Clin Exp Allergy 36: 15461555.

19. Ozdemir C, Akdis M, Akdis CA (2009) T regulatory cells and their counterparts: masters of immune regulation. Clin Exp Allergy 39: 626-639.

20. Akdis CA, Akdis M (2009) Mechanisms and treatment of allergic disease in the big picture of regulatory T cells. J Allergy Clin Immunol 123: 735-746.

21. Onishi Y, Fehervari Z, Yamaguchi T, Sakaguchi S (2008) Foxp3 ${ }^{+}$natural regulatory $T$ cells preferentially form aggregates on dendritic cells in vitro and actively inhibit their maturation. Proc Natl Acad Sci USA 105: 10113-10118.

22. Tversky JR, Bieneman AP, Chichester KL, Hamilton RG, Schroeder JT (2010) Subcutaneous allergen immunotherapy restores human dendritic cell innate immune function. Clin Exp Allergy 40: 94-102.

23. Kearley J, Robinson DS, Lloyd CM (2008) CD4 ${ }^{+} \mathrm{CD} 25^{+}$regulatory T cells reverse established allergic airway inflammation and prevent airway remodeling. $J$ Allergy Clin Immunol 122: 617-624.

24. Hartl D, Koller B, Mehlhorn AT, Reinhardt D, Nicolai T, et al. (2007) Quantitative and functional impairment of pulmonary $\mathrm{CD} 4^{+} \mathrm{CD} 25 \mathrm{hi}^{+}$regulatory $\mathrm{T}$ cells in pediatric asthma. J Allergy Clin Immunol 119: 1258-1266

25. Bluestone JA, Abbas AK (2003) Natural versus adaptive regulatory T-cells. Nat Rev Immunol 3: 253-257.

26. Hawrylowicz CM, O'Garra A (2005) Potential role of interleukin-10-secreting regulatory $T$ cells in allergy and asthma. Nat Rev Immunol 5: 271-283. 
Citation: Tsai YG, Lin CY (2011) Mechanism of Regulatory T Cells During Allergen-Specific Immunotherapy: from the Past to Future. J Aller Ther S7:005. doi:10.4172/2155-6121.S7-005

Page 4 of 4

27. Tsai YG, Kuender DY, Niu DM, Chien JW, Lin CY (2010) TLR2 agonists enhance $\mathrm{CD} 8^{+}$Foxp $3^{+}$regulatory $\mathrm{T}$ cells and suppress Th2 immune responses during allergen immunotherapy. J Immunol 184: 7229-7237.

28. Akdis M, Blaser K, Akdis CA (2005) T regulatory cells in allergy: novel concepts in the pathogenesis, prevention, and treatment of allergic diseases. J Allergy Clin Immunol 116: 961-968.

29. Guerra F, Carracedo J, Solana-Lara R, Sánchez-Guijo P, Ramírez R (2001) TH2 lymphocytes from atopic patients treated with immunotherapy undergo rapid apoptosis after culture with specific allergens. J Allergy Clin Immunol 107: 647-653.

30. Mobs C, Slotosch C, Loffler H, Jakob T, Hertl M, et al. (2010) Birch pollen immunotherapy leads to differential induction of regulatory T cells and delayed helper T cell immune deviation. J Immunol 184: 2194-2203.

31. Akdis CA, Blesken T, Akdis M, Wuthrich B, Blaser K (1998) Role of interleukin 10 in specific immunotherapy. J Clin Invest 102: 98-106.

32. Gorelik L, Constant S, Flavell RA (2002) Mechanism of transforming growth factor $\beta$-induced inhibition of T helper type 1 differentiation. J Exp Med 195: 1499-1505.

33. Chen W, Jin W, Hardegen N, Lei KJ, Li L, et al. (2003) Conversion of peripheral $\mathrm{CD} 4{ }^{+} \mathrm{CD} 25$ - naive $\mathrm{T}$ cells to $\mathrm{CD} 4^{+} \mathrm{CD} 25^{+}$regulatory $\mathrm{T}$ cells by TGF- $\beta$ induction of transcription factor Foxp3. J Exp Med 198: 1875-1886.

34. Fantini MC, Becker C, Monteleone G, Pallone F, Galle PR, et al. (2004) Cutting edge: TGF- $\beta$ induces a regulatory phenotype in $C D 4^{+} C D 25^{+} \mathrm{T}$ cells through Foxp3 induction and downregulation of Smad7. J Immunol 172: 5149-5153.

35. Gorelik L, Fields PE, Flavell RA (2000) Cutting edge: TGF- $\beta$ inhibits Th type 2 development through inhibition of GATA-3 expression. J Immunol 165: 4773-4777.

36. Ablamunits V, Bisikirska BC, Herold KC (2008) Human regulatory CD8 T cells. Ann N Y Acad Sci 1150: 234-238.

37. Niederkorn JY (2008) Emerging concepts in CD8(+) T regulatory cells. Curr Opin Immunol 20: 327-331.

38. Wang YM, Alexander SI (2009) CD8 regulatory T cells: what's old is now new. Immunol Cell Biol 87: 192-193.

39. Karlsson I, Malleret B, Brochard P, Delache B, Calvo J, et al. (2007) FoxP3+CD25+CD8+ T-cell induction during primary simian immunodeficiency virus infection in cynomolgus macaques correlates with low CD4+ T-cell activation and high viral load. J Virol 81: 13444-13455.

40. Joosten SA, Ottenhoff TH (2008) Human CD4 and CD8 regulatory T cells in infectious diseases and vaccination. Hum Immunol 69: 760-770.

41. Tennakoon DK, Mehta RS, Ortega SB, Bhoj V, Racke MK, et al. (2006) Therapeutic induction of regulatory, cytotoxic CD8+ T cells in multiple sclerosis. J Immunol 176: 7119-7129.

42. Brimnes J, Allez M, Dotan I, Shao L, Nakazawa A, et al. (2005) Defects in CD8+ regulatory $\mathrm{T}$ cells in the lamina propria of patients with inflammatory bowel disease. J Immunol 174: 5814-5822.

43. Bisikirska B, Colgan J, Luban J, Bluestone JA, Herold KC (2005) TCR stimulation with modified anti-CD3 mAb expands CD8+ T cell population and induces CD8+CD25+Tregs. J Clin Invest 115: 2904-2913.

44. Mahic M, Henjum K, Yaqub S, Bjørnbeth BA, Torgersen KM, et al. (2008) Generation of highly suppressive adaptive CD8(+)CD25(+)FOXP3(+) regulatory $\mathrm{T}$ cells by continuous antigen stimulation. Eur J Immunol 38: 640-646.

45. Lu L, Cantor H (2008) Generation and regulation of CD8(+) regulatory T cells. Cell Mol Immunol 5: 401-406.

46. Smith TR, Kumar V (2008) Revival of CD8+ Treg-mediated suppression. Trends Immunol 29: 337-342.

47. Siegmund K, Rückert B, Ouaked N, Bürgler S, Speiser A, et al. (2009) Unique phenotype of human tonsillar and in vitro-induced FOXP3+CD8+ T cells. J Immunol 182: 2124-2130.

48. Yamada A, Ohshima Y, Yasutomi M, Ogura K, Tokuriki S, et al. (2009) Antigenprimed splenic CD8+ T cells impede the development of oral antigen-induced allergic diarrhea. J Allergy Clin Immunol 123: 889-894.

49. Cohen JJ, Duke RC, Fadok VA, Sellins KS (1992) Apoptosis and programmed cell death in immunity. Annu Rev Immunol 10: 267-293.

This article was originally published in a special issue, Pulmonary developmental biology handled by Editor(s). Dr. Rodolfo de Paula Vieira, University Hospital Freiburg, German
50. Ohta K, Yamashita N (1999) Apoptosis of eosinophils and lymphocytes in allergic inflammation. J All Clin Immunol 104: 14-21.

51. Guerra F, Carracedo J, Madueno JA, Sanchez-Guijo P, Ramirez R (1999) Allergen induce apoptosis in lymphocytes from atopic patients. Human Immunol 60: 840-847.

52. Guerra F, Carracedo J, Solanan-Lara R, Sanchez-Guijo P, Ramirez R (2001) $\mathrm{TH} 2$ lymphocytes from atopic patients treated with immunotherapy undergo rapid apoptosis after culture with specific allergens. J All Clin Immunol 107: 647-653.

53. Tsai YG, Chien JW, Chen WL, Shieh JJ, Lin CY (2005) Induced apoptosis of $\mathrm{TH} 2$ lymphocytes in asthmatic children treated with Dermatophagoides pteronyssinus immunotherapy. Pediatr Allergy Immunol 16: 602-608.

54. Wilson DR, Lima MT, Durham SR (2005) Sublingual immunotherapy for allergic rhinitis: systematic review and metaanalysis. Allergy 60: 4-12.

55. Bohle B, Kinaciyan T, Gerstmayr M, Radakovics A, Jahn-Schmid B, et al (2007) Sublingual immunotherapy induces IL-10-producing $T$ regulatory cells, allergen- specific T-cell tolerance, and immune deviation. J Allergy Clin Immunol 120: 707-713.

56. Lue KH, Lin YH, Sun HL, Lu KH, Hsieh JC, et al. (2006) Clinical and immunologic effects of sublingual immunotherapy in asthmatic children sensitized to mites: a double-blind, randomized, placebo-controlled study. Pediatr Allergy Immuno 17: 408-415

57. Ciprandi G, Cirillo I, Fenoglio D, Marseglia G, Tosca MA (2006) Sublingua immunotherapy induces spirometric improvement associated with IL-10 production: preliminary reports. Int Immunopharmacol 6: 1370-1373.

58. Ciprandi G, De Amici M, Tosca MA, Pistorio A, Marseglia GL (2009) Sublingual immunotherapy affects specific antibody and TGF-b serum levels in patients with allergic rhinitis. Int J Immunopathol Pharmacol 22: 1089-1096.

59. Allam JP, Wurtzen PA, Reinartz M, et al. (2010) Phl p 5 resorption in human oral mucosa leads to dose-dependent and timedependent allergen binding by oral mucosal Langerhans cells, attenuates their maturation, and enhances their migratory and TGF-b1 and IL-10- producing properties. J Allergy Clin Immuno 126: $638-645$

60. Wakkach A, Fournier N, Brun V, Breittmayer JP, Cottrez F, et al. (2003) Characterization of dendritic cells that induce tolerance and T regulatory 1 cell differentiation in vivo. Immunity 18: 605-617.

61. Yang IA, Fong KM, Holgate ST, Holloway JW (2006) The role of Toll-like receptors and related receptors of the innate immune system in asthma. Cur Opin Allergy Clin Immunol 6: 23-28.

62. Francis JN, Durham SR (2004)Adjuvants for allergen immunotherapy: experimenta results and clinical perspectives. Curr Opin Allergy Clin Immunol. 4:543-548.

63. Creticos PS, Chen YH, Schroeder JT (2004) New approaches in immunotherapy: allergen vaccination with immunostimulatory DNA. Immunol Allergy Clin North Am 24: 569-581.

64. Lombardi V, Van Overtvelt L, Horiot S, Moussu H, Chabre H, et al. (2008) Tolllike receptor 2 agonist Pam3CSK4 enhances the induction of antigen-specific tolerance via the sublingual route. Clin Exp Allergy 38: 1819-1829.

65. Taylor RC, Richmond P, Upham JW (2006) Toll-like receptor 2 ligands inhibit TH2 responses to mite allergen. J Allergy Clin Immunol 117:1148-1154.

66. Zhou C, Kang XD, Chen Z (2008) A synthetic Toll-like receptor 2 ligand decreases allergic immune responses in a mouse rhinitis model sensitized to mite allergen. J Zhejiang Univ Sci B 9: 279-285. 